\title{
Phytotoxic and antibacterial assays of crude methanolic extract of Mentha longifolia (Linn.)
}

\author{
Rahmat Ali Khan ${ }^{1 \star}$, Faridullah Khan ${ }^{1}$, Mushtaq Ahmed ${ }^{1}$, Abdus Sabur Shah, Noor Aslam \\ Khan ${ }^{1}$, Muhammad Rashid Khan ${ }^{2}$ and Mir Sadiq Shah ${ }^{1}$. \\ ${ }^{1}$ Department of Biotechnology, University of Science and Technology, Bannu, Pakistan. \\ ${ }^{2}$ Department of Biochemistry, Faculty of Biological Sciences, Quaid-i-Azam University, Pakistan.
}

Accepted 9 September, 2011

\begin{abstract}
Mentha longifolia (Horse Mint; syn. M. sylvestris L.) is a well known species in the genus Mentha (mint) widely applied in medicine as a constituent of various drugs, and is often used in aromatherapy. The current study was designed to investigate the antibacterial and phytotoxic capacity of methanolic extract of $\boldsymbol{M}$. longifolia. Five hundred gram of shade dried whole plant in powdered form was subjected to extract in methanol, which yielded approximately $\mathbf{8 0} \mathrm{g}$ of plant extract. The extract was evaluated for in vitro bioassay including antibacterial activity against Staphylococcus aureus, Micrococcus luteus, Escherichia coli and Pseudomonas aeruginosa, through agar well diffusion technique. The herbicidal potency of the extract was also evaluated by phytotoxic assay in two modes. The extract showed maximum antibacterial potential in various concentrations, and also showed a significant inhibition in growth of shoot and root in both modes of phytotoxic assay, that is, plate and field study might be due to the presence of bioactive constituents in extract.
\end{abstract}

Key words: Mentha longifolia, antibacterial, methanolic extract, phytotoxic assay.

\section{INTRODUCTION}

From the very beginning, man is gifted with plants used for curing diseases or in preparation of new drugs. According to reports, $30 \%$ of the drugs are obtained from medicinal plants (Grabley and Thiericke, 1999). Efforts have been made to detect the active constituents responsible for such properties in plants. However, the scientists showed an increasing interest to extract new antimicrobial bioactive compounds from various natural sources, like folk medicinal plants and extracts obtained from medicinal plants (Khan et al., 2009; Khan et al., $2010 \mathrm{a}, \mathrm{b}, \mathrm{c})$. Food protection against pathogenic microbes is another challenge for scientists, who have focused to develop crop production to cope with the needs of the world population, but unfortunately every

*Corresponding author. E-mail: Rahmatgul_81@yahoo.com. Tel: 0928633022 . Fax: 0928624987.

Abbreviations: MLME, Mentha longifolia methanolic extract; MIC, minimum inhibition concentration; DMSO, dimethyl sulfoxide; $\mathbf{m m}$, millimeter; $\boldsymbol{\mu l}$, microlitre. year the yield of crop losses, due to insects and plant diseases caused by various pathogens and slow biodegradation of herbicides. Many extracts, obtained from medicinal plants, herbs and spices, have displayed antimicrobial activities and might be a source against food spoilage and pathogens (Bagamboula et al., 2003). Hence, the present study has been carried out to investigate the antibacterial and phytotoxic capacity of methanolic extract of $M$. longifolia.

\section{MATERIALS AND METHODS}

Plant collection

Plant of $M$. longifolia (Linn.) at maturity was collected from district Bannu (Pakistan) during the month of April 2009, and was identified by Dr. Abdur Rehman Khan, Chairperson Department of Botany, G.P.G. College, Bannu. All parts of the plant (leaves, stem, flowers, seeds and roots) were shade dried at room temperature for about two weeks, chopped and ground mechanically.

Preparation of plant extract

Dry powder of $M$. longifolia weighing $500 \mathrm{~g}$ was extracted with $5 \mathrm{~L}$ 


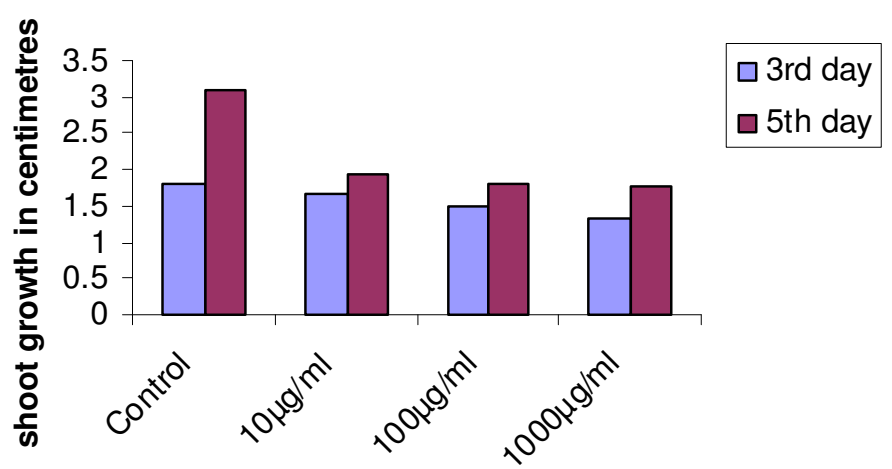

Concentration of $M$. longifolia extract

Figure 1. Shoot growth of wheat in plate study.

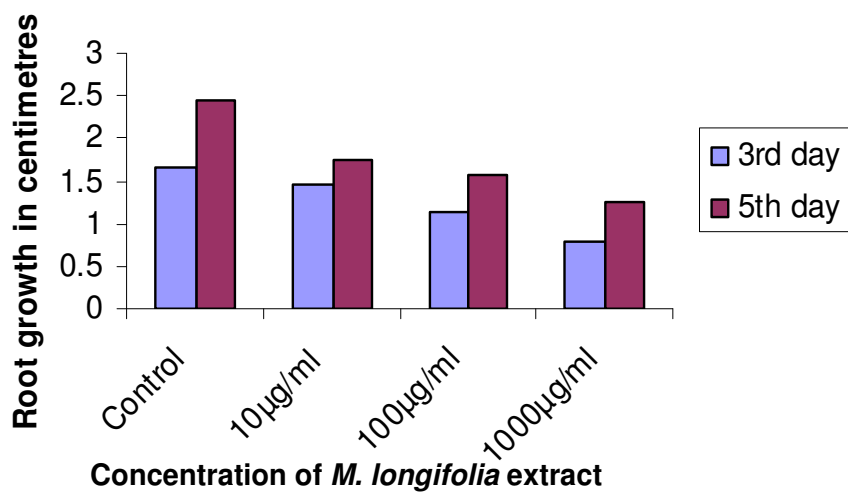

Figure 2. Root growth of wheat in plate study.

of methanol using continuous shaking. After a week the extract was filtered through Whatmann filter paper No. 45, and the filtrate was evaporated through rotary vacuum evaporator to obtain methanolic crude extract (MLME) which was cooled at room temperature and stored at $4^{\circ} \mathrm{C}$ for further phytochemical, in vitro investigations.

\section{Phytotoxic bioassay}

Two methods were used to determine the phytotoxic or allelopathic potential of the crude extract. The phytotoxic (allelopathic) assay was determined according with the modified protocol of McLaughlin (1988) in his work. The methanolic extract of $M$. longifolia was dissolved at varying dilutions $(10,100$ and $1000 \mu \mathrm{g} / \mathrm{ml})$ obtained from stock solution ( $5 \mathrm{mg} / 5 \mathrm{ml}$ in methanol) in respective solvent in duplicate. Wheat seeds were washed with $\mathrm{dH}_{2} \mathrm{O}$. The Petri plates were autoclaved at $121^{\circ} \mathrm{C}$ for about $15 \mathrm{~min}$ and provided with filter papers. $5 \mathrm{ml}$ of various dilutions of the extract was poured in each plate and then the solvent was evaporated. After this $5 \mathrm{ml}$ of $\mathrm{dH}_{2} \mathrm{O}$ was poured in each plate and ten seeds of wheat were placed in each plate at equal distance and incubated at $28^{\circ} \mathrm{C}$ for 7 days. After 3 days, root and shoot inhibition was recorded, and again after 4 days, it was repeated. Fresh and dry weight of the plant in each of the Petri plate was also determined. In field study, the wheat seeds were grown in soil (Approximately $100 \mathrm{~g}$ ), in each of the three sets. Each set was provided with similar environmental conditions. After 15 days the length of each plant in each set was recorded. Then, each set was treated with aqueous plant extract with varying dilutions $(10,100$ and $1000 \mu \mathrm{g} / \mathrm{ml})$ obtained from initial stock (5 $\mathrm{mg} / 5 \mathrm{ml}$ in $\mathrm{dH}_{2} \mathrm{O}$ ) solution. The length of the plant in each set was again recorded after 10 days to find out the inhibition activity of plant extract when solvent was water. Each set was taken in duplicate. Fresh and dry weight of the plant in each of the set was also determined.

\section{The antibacterial activity}

Antibacterial activities of MLME were evaluated following agar well diffusion method. From $24 \mathrm{~h}$ old broth, a loop with about $10^{4}$ to $10^{6}$ suspension of each bacterium was applied on the surface of Mueller-Hinton agar plates. With the help of a sterile cork borer, wells were dug in the agar. Then, $67 \mu \mathrm{l}$ of various dilutions obtained from stock solution in Dimethyl sulfoxide (DMSO), was subjected to the respective wells and the plates were then incubated at $37^{\circ} \mathrm{C}$ for $24 \mathrm{~h}$ and next morning zone of inhibition was measured in millimeters $(\mathrm{mm})$. This activity was studied for Escherichia coli, Micrococcus luteus, Staphylococcus aureus and Pseudomonas aeruginosa. Dimethyl sulfoxide (DMSO) was used as negative control.

\section{RESULTS}

\section{Phytotoxic assay}

The results for phytotoxic assay of plant extract were recorded against wheat seeds growth under controlled conditions in growth room.

The current study was performed to investigate the various parameters of allelopathic potential of the extract. The phytotoxic study was performed in two groups, that is, plate study and field study, and the same procedure were followed for both of these experiments. In field study, growth inhibition was evaluated with $\mathrm{dH}_{2} \mathrm{O}$ as solvent. A significant inhibition was shown by the extract at various concentrations when result collected after 3 rd, 5 th and after 10 days of the experiments. Total fresh and dry weight of all groups was recorded and it was found that the various concentrations in both experiments remained effective as compared to control. A remarkable inhibition was shown in the growth of root and shoot (for plate study) (Figures 1 and 2) and also inhibition in the growth of shoot and fresh, dry weight was recorded for field study at 10,100 and $1000 \mu \mathrm{g} / \mathrm{ml}$ (Figures 3 and 4), respectively.

\section{Antibacterial activity}

The results for in vitro antibacterial activity for various concentrations ( 1,3 and $5 \mathrm{mg} / \mathrm{ml}$ in DMSO) of the plant extract of M. longifolia (Linn.) against gram positive and gram negative strains, is presented in Table 1 . The methanolic extract of plant revealed a remarkable activity against the following strains, $S$. aureus, M. luteus, E. coli and $P$. aeruginosa.

The methanolic extract in various concentrations remained active against all the tested strains with extract concentration of 1,3 and $5 \mathrm{mg} / \mathrm{ml}$ for each, and it 


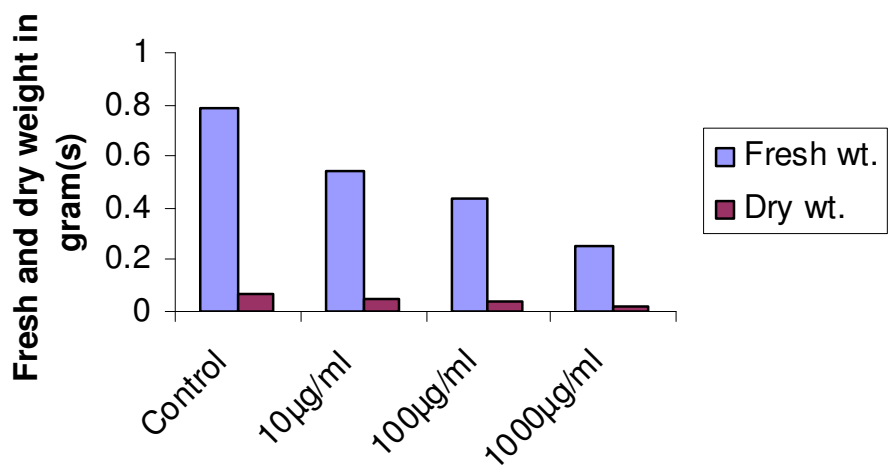

Concentration of $M$. longifolia extract

Figure 3. Fresh and dry weight of wheat in field study.

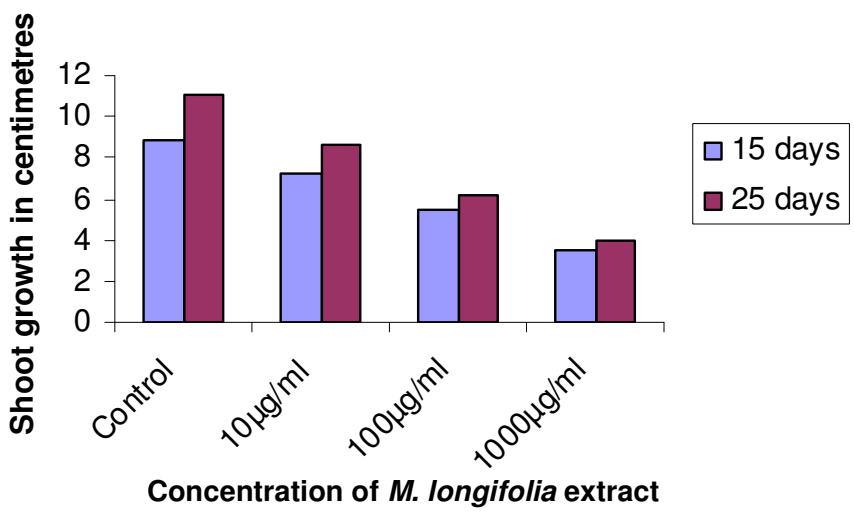

Figure 4. Shoot growth of wheat in field study.

Table 1. Zone of inhibition of different concentrations of Mentha longifolia (Linn) against bacterial strains.

\begin{tabular}{|c|c|c|c|c|c|c|c|c|}
\hline \multirow{2}{*}{ Group } & \multicolumn{2}{|c|}{ M. Iuteus } & \multicolumn{2}{|c|}{ S. aureus } & \multicolumn{2}{|c|}{ E. coli } & \multicolumn{2}{|c|}{$P$. aeruginosa } \\
\hline & Conc. & Zone (mm) & Conc. & Zone (mm) & Conc. & Zone (mm) & Conc. & Zone (mm) \\
\hline MLME & 1 & 18 & 1 & 18 & 1 & 19 & 1 & 16 \\
\hline \multirow{2}{*}{ DMSO } & 5 & 22 & 5 & 25 & 5 & 24 & 5 & 22 \\
\hline & - & 1 & - & 0.8 & - & 0.9 & - & 1.2 \\
\hline
\end{tabular}

$\mathrm{DMSO}=+$ control, - = No inhibition, Conc. $=$ concentration.

induced a remarkable growth inhibition capacity towards the tested strains.

\section{DISCUSSION}

Native medicinal plants may offer remarkable source of natural antioxidants to be employed as dietary supplements or used for food industry. Medicinal plants as appreciable source of antioxidant phytochemicals have received growing attention as potential chemo preventive agents. Epidemiological investigations have reported that antioxidants have a protective role in most of health diseases. Today, $30 \%$ of drugs are obtained from medicinal plants (Grabley and Thiericke, 1999; Sahreen et al., 2010, 2011a, b). Researchers have focused on introducing new antimicrobial drugs from natural resources to overcome the emerged antibiotic 
resistant strains as well as adverse side effects of synthetic drugs. The data of our current study revealed that methanolic extract of plant has tremendous antibacterial property against some clinically important pathogens. The present study is well supported by Narod et al. (2004) who reported that methanolic extract of leaf and stem of Toddalia asiatica contained activity against gram positive and gram negative bacteria. Fungi make the food materials unfit for human by lowering their nutritive value (Janardhana et al., 1998). The collected data suggested that plant extract was tremendous in preventing bacterial and fungal growth, probably due to bioactive components like flavonoids, terpenoids and saponins. Several investigations attributed the antimicrobial activity of plant extract to the presence of phenolic compounds (Bayder et al., 2006; Rodriguez et al., 2007; Khan et al., 2011a, b, c) like flavoonids and saponins with antifungal activities (Aboaba and Mohanta, 2007). The results obtained for phytotoxicity activity for MLME revealed that it blocked the growth of wheat root as well as shoot contrary to control plants treated with $\mathrm{dH}_{2} \mathrm{O}$. The methanolic extract exhibited significant inhibition of growth of both root and shoot. Our work might match with that reported by Javaid (2009) for bioactive constituents investigated in water extract of Withania somnifera and Datura alba, which markedly blocked the growth of both root and shoot of Rumex deutatus L., a significant competitive weed in wheat during allelopathic screening assays. Similar facts were found by Kordali et al. (2008) for complete growth inhibition of both seedling and roots due to the presence of phenolic compounds obtained from Turkish origanum essential oil, when compared with reference compounds/molecules.

\section{REFERENCES}

Bagamboula CF, Uythendeale M, Debevere J (2003). Antimicrobial effect of spices and herbs on Shigella sonnei and Shigella flexneri. J. Food Prot., 66: 668-673.

Bayder NG, Sagdic O, Ozkan G, Cetin S (2006). Determination of antibacterial effects and total phenolic contents of grape (Vitis vinifera L.) seed extracts. Int. J. Food Sci. Technol., 41: 799-804.

Grabley S, Thiericke R (1999). Bioactive agents from natural sources: trends in discovery and application. Adv. Biochem. Eng. Biotechnol., 64: $101-54$.

Javaid A (2009). Role of effective microorganisms in sustainable agricultural productivity. In: Advances in sustainable agriculture. Springer.
Khan MR, Rizvi W, Khan GN, Khan RA, Sheen S (2009). Carbon tetrachloride-induced nephrotoxicity in rats: Protective role of Digera muricata. J. Ethnopharmacol., 122: 91-99.

Khan RA, Khan MR, Sahreen S (2010a). Evaluation of Launaea procumbens use in renal disorders: A rat model. J. Ethnopharmacol., 128: $452-461$.

Khan RA, Khan MR, Sahreen S, Bukhari J (2010b). Prevention of $\mathrm{CCl}_{4}^{-}$ induced nephrotoxicity with Sonchus asper in rat. Food Chem. Toxicol., 23: 1304-1321.

Khan RA, Khan MR, Sahreen S, Bukhari J (2010c). Antimicrobial and Phytotoxic activity of various fractions of Sonchus asper. Afr. J. Biotechnol., 47: 3877-3683.

Khan RA, Khan MR, Sahreen S, Jan S, Bokhari J, Rashid U (2011b). Phytotoxic characterization of various fractions of Launaea procumbens. Afr. J. Biotechnol., 10: 5377-5380.

Khan RA, Khan MR, Sahreen S, Jan S, Bokhari J, Rashid U (2011c). Prevention of $\mathrm{CCl}_{4}$ induced adrenal oxidative stress in rat by Sonchus asper. J. Med. Plants Res., 5(15): 3347-3350.

Khan RA, Khan MR, Sahreen S (2011a). Protective effect of Sonchus asper extracts against experimentally-induced lung injuries in rats: A novel study. Exp. Toxicol. Pathol., doi: 10.1016/j.etp. 01.007

Kordali S, Cakir A, Ozer H, Cakmakci R, Kesdek M, Mete E (2008). Antifungal, Phytotoxic and insecticidal properties of essential oil isolated from Turkish Origanum acutidens and its three components, carvacrol, thymol and p-cymene. Bioresour. Technol., 99: 8788-8795.

Mohanta TK, Patra JK, Rath SK, Pal DK, Thatoi HN (2007). Evaluation of antimicrobial activity and phytochemical screening of oils and nuts of Semicarpus anacardium L.F. Sci. Res. Essay, 2: 486-490.

Narod FB, Gurib-Fakim A, Subratty AH (2004). Biological investigations into Antidesma madagascariense Lam. (Euphorbiaceae), Faujasiopsis flexuosa (Lam.) C. Jeffery (Asteraceae), Toddalia asiatica (L.) Lam. and Vepris lanceolata (Lam.) G. Don (Rutaceae). J. Cell Mol. Biol., 3: 15-21.

Rodriguez N, Amils R, Jimenez-Ballesta R, Rufo L, Dela-Fuente V (2007). Heavy metal content in Erica andevalensis: An endemic plant from extreme acidic environment of Tinto River and its soils. Arid Lands Res. Manage., 21: 51-65.

Sahreen S, Khan MR, Khan RA (2010). Evaluation of antioxidant activities of various solvent extracts of Carissa opaca fruits. Food Chem., 122: 1205-1211.

Sahreen S, Khan MR, Khan RA (2011a). Hepatoprotective effects of methanol extract of Carissa opaca leaves on $\mathrm{CCl}_{4}$-induced damage in rat. BMC Comp. Altern. Med., 11: 48 doi: 10.1186/1472-6882-11-48.

Sahreen S, Khan MR, Khan RA (2011b). Phenolic compounds and antioxidant activities of Rumex hastatus D. Don. leaves. J. Med. Plants Res., 5(13): 2755-2765. 